\title{
Influence of Retrieval Distractor and Sequencing Distractor on Phonological Encoding Performance in Children with and without Speech Sound Disorders
}

\author{
Ji-Hye Hwang, Ji-Wan $\mathrm{Ha}^{\mathrm{b}, \mathrm{c}}$ \\ ${ }^{a}$ Department of Speech and Language Pathology, Graduate School of Rehabilitation, Daegu University, Gyeongsan, Korea \\ ${ }^{b}$ Department of Speech Pathology, Daegu University, Gyeongsan, Korea \\ 'International Institute of Rehabilitation Science, Daegu University, Gyeongsan, Korea
}

Correspondence: Ji-Wan $\mathrm{Ha}, \mathrm{PhD}$ Department of Speech Pathology, Daegu University, 201 Daegudae-ro, Jillyang-eup, Gyeongsan 38453, Korea

Tel: $+82-53-850-4327$

Fax: +82-53-850-4329

E-mail: jw-ha@daegu.ac.kr

Received: July 21, 2019

Revised: September 2, 2019

Accepted: September 2, 2019
Objectives: We investigated the phonological encoding performance of children with and without speech sound disorders (SSD) using a priming task composed of a retrieval distractor and a sequencing distractor. Methods: The subjects were children with SSD, children with SSD with language delay (SSD+LD), and typically developing children (TD) aged 4-5 years. A picture was given with distractor, in which children should ignore the distractor and name the picture. The three kinds of distractors (retrieval, sequencing, and unrelated distractor) were presented auditorily at each of three stimulus onset asynchrony (SOAs; $-300 \mathrm{~ms}, 0 \mathrm{~ms},+300 \mathrm{~ms})$. Results: Both the pure SSD and the SSD+LD groups showed significant difference in accuracy, and the SSD+LD group showed significant difference in reaction time and error rate compared with the TD group. Both retrieval and sequencing distractors significantly improved the task performance when compared to the unrelated distractor. The retrieval distractor promoted the performance in all SOAs, whereas the sequencing distractor promoted subjects' performance only in SOA 0 ms. With the unrelated distractor, phonological inactivation errors were significantly more frequent. However, phonation activation errors were significantly more frequent in both retrieval and sequencing distractors. Conclusion: The SSD group, in particular the SSD+LD group, may be more sensitive to distractors than the TD group. However, depending on the type of distractors, a positive priming effect may be expected, and the effect may vary depending on the point of presentation of distractors.

Keywords: Speech sound disorder, Phonological encoding, Priming effect, Retrieval distractor, Sequencing distractor
말소리장애 아동의 음운 또는 조음 문제를 가장 손쉽게 평가할 수 있는 방법 중 하나로 그림 이름대기 과제를 들 수 있다. 그림 이름 대기는 얼핏 단순한 과제로 보일 수 있으나, 해당 그림을 시각적으 로 분석한 후 목표어휘를 떠올리고 그에 대한 음운정보들을 인출, 배열한 후 정확하게 조음하는 일련의 과정은 생각처럼 간단하지 않다. 먼저 그림을 보자마자 의미적으로 연관 있는 개념들이 자동 적으로 활성화되는 개념화부(conceptualization)가 시작된다. 그 후 해당 의미표상의 어휘를 선택하고 선택된 어휘의 음운표상을 인출한 후 말소리 형태를 갖추는 형성부(formulation)를 거쳐, 그
말소리 형태를 발음하기 위해 요구되는 조음운동을 실시하는 조음 부(articulation) 단계에 최종적으로 이르게 된다(Levelt, 1989). 이 가운데 형성부에서 일어나는 음운처리 과정을 좀 더 자세히 살펴 보면, 음운표상의 인출(Rubin \& Liberman, 1983), 인출된 음운표 상의 음운산출완충기(phonological output buffer)상의 일정 시간 보유, 해당 음운표상에 포함된 음소들의 인출, 두운에서 각운까지 위치에 맞게 인출된 음소들의 점진적 배열(Dell, Chang, \& Griffin, 1999)이라는 다소 복잡한 처리 과정들을 모두 거쳐야 한다. 이와같 은 일련의 과정을 ‘음운산출계획’ 또는 ‘음운부호화’라고도 한다. 
말소리장애 아동 중 일부는 이러한 음운부호화 단계에서 특히 어려움을 보인다(Dodd, 2005). 이는 음운산출완충기에서 음운계 획을 집합시키는 것(assembly)의 결함으로(Dodd \& McComack, 1995) 설명할 수 있으며, 이와 같은 음운계획상의 결함은 말소리장 애 하위집단인 비일관적 음운장애의 기저원인으로 언급되기도 하 였다(Bradford \& Dodd, 1994, 1996; Bradford-Heit \& Dodd, 1998; Chiat, 1983; Dodd \& McComack, 1995). 이와 관련하여 국내에서 도 말소리장애 아동은 음운표상의 질이 정확하지 않고 새로운 음 운표상을 부호화하는 능력에 결함을 보인다는 연구(Kim \& Ha, 2014), 특히 언어발달지체를 동반한 말소리장애 아동의 경우 음운 표상 부호화에 더욱 결함을 보인다는 연구(Bae, 2018) 등을 찾아볼 수 있다. 그러나 선행연구들은 음운부호화에 대한 광범위한 결함 을 보고하였을 뿐, 음운산출계획 중 구체적으로 어떠한 특정 과정 에서 말소리장애 아동이 보다 어려움을 보이는지를 밝혀주지는 못 하였다. 음운부호화 단계에서 음소의 '인출'과 ‘배열’이라는 적극적 인 인지활동을 하는 만큼, 이 두 과정을 구분하여 음운부호화 과정 을 보다 심층적으로 살펴보려는 노력이 요구된다. 음운부호화 단계 에서 음소의 인출과 배열은 저장되어 있는 정보가 자동적으로 활 성화되는 정적인 인지활동이 아니라, 인출한 음운표상의 템플릿과 동일하게 각 음소들을 선택하고 순서화하는 능동적인 인지활동이 다. 따라서 인출과 배열능력을 평가하기 위해서는 보다 동적인 인지 활동이 요구되는 과제를 활용해야 할 것이며, 이를 위해 몇몇 연구 자들은 점화자극(prime)을 이용하여 그것이 목표반응에 미치는 점화효과(priming effect)를 살펴본 바 있다.

점화효과란 목표자극과 매우 근접한 시간에 제시된 관련자극 (점화자극)이 목표자극의 처리에 미치는 영향을 말하며, 보편적으 로 점화자극은 목표자극에 선행하여 제시된다(Meyer \& Schvaneveldt, 1971). 점화자극을 통해 목표단어의 활성화가 일어날 경우 '정적 점화효과(positive priming effect)', 즉, 촉진효과가 일어나, 목 표반응의 반응속도는 빨라지고 정확도는 높아진다. 반대로 점화자 극이 목표단어의 활성화를 방해하면, '억제효과'가 나타나 목표반 응의 반응속도는 느려지고 정확도는 낮아진다. 이때 목표자극과 점 화자극 간 시간 간격을 자극제시시간(stimulus onset asynchrony, $\mathrm{SOA})$ 이라고 하는데, 자극제시시간을 조작하면 전체 단어산출 과 정에서 음운정보의 처리 과정만 선택적으로 살펴보는 것이 가능하 다(Posner \& Snyder, 1975). 예를 들어 점화자극을 목표자극 전인 자극제시시간에 제시할 경우 단어산출 과정의 초기 단계에서 일어 난 효과를 반영한다. 반면 목표자극 후인 +자극제시시간에 점화자 극을 제시할 경우 단어산출 과정의 후기 단계, 즉 어휘후 단계 (post-lexical stage)에서 발생한 효과를 반영하는데, 이는 음운정보
처리단계, 즉 음운부호화 단계에 해당한다. 이와 같이 구어산출 과 정에서 어휘후 단계를 살펴보기 위해 점화자극을 목표자극보다 후 행하는 시점인 +자극제시시간으로 재설정한 연구들이 발표됨에 따라(Strijkers \& Costa, 2011; Wilshire, Singh, \& Tattersall, 2016), 점화자극의 시점은 목표자극 이전으로 고정되지 않고 보다 유동적 이 되었다.

앞에서 언급하였듯이 점화는 촉진효과와 억제효과를 둘 다 초 래할 수 있다. 그러나 촉진과 억제는 서로 상대적인 개념으로 설명 된다(Brooks \& MacWhinney, 2000). 예를 들어 그림 이름대기 과 제 시 목표자극 이외의 모든 자극은 대상자의 목표활동을 방해하 며, 점화자극도 마찬가지이다. 단, 목표반응과 동일한 자극(예: ‘나 무’를 말해야 할 때 /나무/가 제시됨) 또는 목표반응의 일부(예: ‘나 무’를 말해야 할 때/나/가 제시됨)가 제시될 경우 목표반응은 촉진 된다. 그 이외의 점화자극은 대상자의 목표활동에 대해 방해요소 로 작용한다. 그러나 이러한 자극들이 모두 동일한 크기의 방해를 유발하는 것은 아니다. 어떤 자극은 매우 방해가 큰 반면, 어떤 자 극은 상대적으로 방해가 작다. 이때 후자는 전자에 비해 목표반응 의 활성화를 상대적으로 촉진시켰다고 할 수 있다. 따라서 목표자 극 이외의 자극은 대부분 목표활동에 대한 방해자극(distractor)이 지만, 기준이 되는 특정 자극, 이를 테면 부저 소리, 비관련어 등과 같은 중립적 자극보다 상대적으로 목표활동을 촉진한다면 이는 촉 진 방해자극이라 할 수 있다. 따라서 'distractor'라는 용어를 우리 말로 ‘방해’ 자극이라고 번역할 때 생길 수 있는 오해, 즉 절대적인 간섭을 한다는 의미로 받아들이면 안 될 것이다.

시각적 분석, 의미활성화, 어휘선택, 음운표상, 음운부호화, 운동 계획, 운동실행의 연속적인 일련의 과정으로 이루어지는 그림 이름 대기 과제의 수행에서 음운부호화는 비교적 후기에 일어는 단계이 다. 선행연구에 의하면 음운표상 인출 이후의 처리 과정은 자극제시 시간 $+200 \mathrm{~ms}$ 와 자극제시시간 $+400 \mathrm{~ms}$ 사이에서 일어난다(Strijkers \& Costa, 2011; Wilshire et al., 2016). 음운부호화가 일어나는 시 점 또한 대략이 즈음으로 보고되었으며, 따라서 선행연구(Strijkers \& Costa, 2011)와 동일하게 본 연구에서도 방해자극이 음운부호화 에 미치는 영향을 살펴보기 위해 자극제시시간 $+300 \mathrm{~ms}$ 에서 방해 자극을 제시하였다. 또한 일부 선행연구에서는 자극제시시간 +300 $\mathrm{ms}$ 뿐 아니라 $-300 \mathrm{~ms}$ 에서도 음운 방해자극에 의한 음운적 촉진이 관찰되었다고 보고되기도 하였다(Jescheniak \& Schriefers, 2001). 해당 처리 과정이 일어나는 시점보다 이전에 방해자극을 제시하여 그것이 미치는 영향의 범위를 일반아동과 비교 분석해 보는 것은 말소리장애 아동의 말처리 과정에 대한 의미 있는 정보를 제공할 것이다. 따라서 본 연구에서도 해당 시점인 $+300 \mathrm{~ms}$ 보다 앞선 자극 
제시시간 $0 \mathrm{~ms}$ 와 자극제시시간 $-300 \mathrm{~ms}$ 에서도 방해자극을 제시 하여, 자극제시시간 조건에 따라 목표활동에 대한 영향을 비교하 고자하였다.

정리하면 본 연구에서는 $-300 \mathrm{~ms}, 0 \mathrm{~ms},+300 \mathrm{~ms}$ 의 자극 제시시 점에서 방해자극이 말소리장애 아동의 음운부호화 능력에 미치는 영향을 살펴보고자 하였다. 음운부호화에 어려움이 있을 경우 어휘 또는 언어능력에도 결함이 있을 수 있다는 선행연구(Dodd, 2005) 에 근거하여, 말소리장애 집단을 언어장애 동반 여부에 따라 순수 말소리장애 집단(pure speech sound disorder, pure SSD)과 언어발 달지체를 동반한 말소리장애 집단(speech sound disorder with language disorder, SSD+LD)으로 구분하여, 이들의 수행력을 일반 집단(typically development, TD)과 비교하였다. 또한 음운부호화 를 인출과 배열이라는 보다 세부적인 처리 과정으로 구분하여 살 펴보기 위해, 인출 방해자극과 배열 방해자극의 두 가지 자극을 선 정한 후 그 영향을 비관련 방해자극과 비교하였다. 이때 인출 방해 자극은 목표단어와 일부 음소가 동일하지 않은 자극을, 배열 방해자 극은 목표단어와음소 배열순서가 동일하지 않은 자극을 의미한다.

이상과 같은 본 연구의 연구질문을 정리하면 다음과 같다. 첫째, 세 집단(pure $\mathrm{SSD}, \mathrm{SSD}+\mathrm{LD}, \mathrm{TD}$ ) 간 점화자극 유형(인출 방해자극, 배열 방해자극, 비관련 방해자극) 및 자극제시시간 조건(-300 ms, 0 $\mathrm{ms},+300 \mathrm{~ms}$ )에 따라 음운부호화 점화 과제의 수행 정확도에 차이 가 있는가? 둘째, 세 집단(pure $\mathrm{SSD}, \mathrm{SSD}+\mathrm{LD}, \mathrm{TD}$ ) 간 자극제시시 간 조건(-300 ms, $0 \mathrm{~ms},+300 \mathrm{~ms}$ ) 간 점화자극 유형(인출 방해자극, 배열 방해자극, 비관련 방해자극) 및 자극제시시간 조건(-300 ms, $0 \mathrm{~ms},+300 \mathrm{~ms}$ )에 따라 음운부호화 점화 과제의 수행 반응시간에 차이가 있는가? 셋째, 세 집단(pure SSD, $\mathrm{SSD}+\mathrm{LD}, \mathrm{TD})$ 간 점화자 극 유형(인출 방해자극, 배열 방해자극, 비관련 방해자극)에 따라 음운부호화 점화 과제 시 나타난 오류유형별(무응답, 비유창성, 음 운 비활성화, 음운 활성화, 의미 활성화) 오류율에 차이가 있는가?

\section{연구방법}

\section{연구대상}

본 연구의 대상은 4 세와 5 세의 pure $\mathrm{SSD}$ 아동 18 명, $\mathrm{SSD}+\mathrm{LD}$ 아 동 8 명, $\mathrm{TD}$ 아동 18 명으로 총 44 명이었다. 모든 대상자는 부모나 교 사에 의해 인지, 운동, 청력 등에 문제가 없다고 보고된 아동이었다. Pure SSD 아동의 구체적인 선정기준은 다음과 같다. (1) 수용·표현 어휘력검사(Receptive \& Expressive Vocabulary Test, REVT; Kim, Hong, Kim, Jang, \& Lee, 2009) 결과, 생활연령에 비해 -1 SD 이상 에 속하는 아동, (2) 취학전 아동의 수용언어 및 표현언어 척도(Pre- school Receptive-Expressive Language Scale, PRES; Kim, Sung, \& Lee, 2003) 결과, 통합언어발달연령이 생활연령과 1 세 미만 차이 나 는 아동, (3) 우리말 조음·음운평가(Urimal Test of Articulation and Phonology, U-TAP; Kim \& Shin, 2004) 결과, 단어 수준에서 자음정확도(PCC)가 $-2 \mathrm{SD}$ 이하인 아동, (4) 한국판 Raven CPM 유 아용 지능검사(Korean Raven's Coloured Progressive Matrices, K$\mathrm{CPM}$; Lim, 2004) 결과, 동작성 지능이 평균 이상인 아동을 대상으 로 하였다. SSD+LD 아동의 구체적인 선정기준은 (1) 수용·표현어 휘력검사(REVT) 결과, 생활연령에 비해 -1 SD 이하에 속하는 아 동, (2) 취학전 아동의 수용언어 및 표현언어 척도(PRES) 결과, 통합 언어발달연령이 생활연령과 1세 이상 차이 나는 아동, (3) 우리말 조음·음운평가(U-TAP) 결과, 단어 수준에서 자음정확도(PCC)가 $-2 \mathrm{SD}$ 이하인 아동, (4) 한국판 Raven CPM 유아용 지능검사(K$\mathrm{CPM}$ ) 결과, 동작성 지능이 평균 이상인 아동이었다. 마지막으로 일반아동은 다음과 같은 선정기준을 적용하여, (1) 수용·표현어휘 력검사(REVT) 결과, 생활연령에 비해 정상 규준에 속하는 아동, (2) 취학전 아동의 수용언어 및 표현언어 척도(PRES) 결과, 통합언 어발달연령이 생활연령과 1 세 미만 차이 나는 아동, (3) 우리말 조 음·음운평가(U-TAP) 결과, 단어 수준에서 자음정확도(PCC)가 정 상범위에 속하는 아동, (4) 한국판 Raven CPM 유아용 지능검사(K$\mathrm{CPM}$ ) 결과, 동작성 지능이 평균 이상인 아동을 대상으로 하였다.

세 집단의 정보를 Table 1에 제시하였다. 세 집단 간 생활월령과 성별에는 유의한 차이가 없었다( $p>.05)$. Pure SSD 집단과 TD 집단 간 수용언어척도, 표현언어척도, 수용어휘력, 표현어휘력, 동작성 지능에는 유의한 차이가 없었으나 $(p>.05)$, 자음정확도에는 유의 한 차이가 있었다 $(p<.05) . \mathrm{SSD}+\mathrm{LD}$ 집단과 $\mathrm{TD}$ 집단 간 동작성 지 능에는 유의한 차이가 없었으나 $(p>.05)$, 수용언어척도 $(p<.05)$, 표 현언어척도, 수용어휘력, 표현어휘력, 자음정확도에는 유의한 차이 가 있었다 $(p<.05)$. 그리고 pure SSD 집단과 $\mathrm{SSD}+\mathrm{LD}$ 집단 간에는 동작성 지능, 자음정확도에는 유의한 차이가 없었으나 $(p>.05)$, 수 용언어척도, 표현언어척도, 수용어휘력, 표현어휘력에는 유의한 차 이가 있었다 $(p<.05)$.

\section{목표어 및 점화자극 선정}

목표단어는 대상자들에게 의미적으로 친숙하고 발음하기 쉬운 단어들로 구성하고자 하였다. 이를 위해 13 개월에서 36 개월 사이 의 영유아용 어휘목록(Choi, 2000; Pae \& Kwak, 2011)에서 적절한 단어들을 1 차 선정하였다. 선정된 단어들 중 초기 발달 음소(/ㅂ),

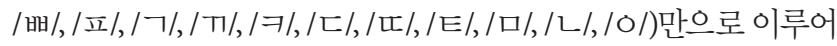
진 2음절 단어들을 추려 2 차 단어목록을 선정하였다. 
Table 1. Participants' characteristics

\begin{tabular}{|c|c|c|c|}
\hline & Pure SSD group $(\mathrm{N}=18$ ) & SSD+LD group $(\mathrm{N}=8$ ) & TD group $(\mathrm{N}=18$ ) \\
\hline \multicolumn{4}{|l|}{ Gender } \\
\hline Male & 10 & 4 & 11 \\
\hline Female & 8 & 4 & 7 \\
\hline Chronological age (mo) & $56.83(4.36)$ & $59.88(4.64)$ & $57.94(5.56)$ \\
\hline \multicolumn{4}{|l|}{ PRES } \\
\hline Receptive language age (raw score) & $40.94(5.55)$ & $30.00(5.07)$ & $43.28(6.94)$ \\
\hline Expressive vocabulary age (raw score) & $39.39(5.80)$ & $27.25(8.24)$ & $44.17(6.21)$ \\
\hline \multicolumn{4}{|l|}{ REVT } \\
\hline Receptive vocabulary (raw score) & $49.67(7.56)$ & $33.88(17.37)$ & $57.50(7.65)$ \\
\hline Expressive vocabulary (raw score) & $54.78(7.72)$ & $35.88(14.85)$ & $62.61(7.84)$ \\
\hline \multicolumn{4}{|l|}{ U-TAP } \\
\hline PCC (\%) & $81.47(5.31)$ & $81.68(8.56)$ & $99.61(1.19)$ \\
\hline K-CPM (raw score) & $20.06(2.07)$ & $18.75(2.38)$ & $22(3.55)$ \\
\hline
\end{tabular}

Values are presented as mean (SD).

$S S D=$ speech sound disorder; $S S D+L D=$ speech sound disorder with language disorder; $T D=$ typically developing; $P C C=$ percentage of consonants correct; PRES=Preschool Receptive \& Expressive Language Scale (Kim, Sung, \& Lee, 2003); REVT=Receptive \& Expressive Vocabulary Test (Kim, Hong, Kim, Jang, \& Lee, 2009); U-TAP=Urimal Test of Articulation and Phonology (Kim \& Shin, 2004); K-CPM= The Korean Colored Progressive Matrices (Lim, 2004).

목표자극에 대한 각 점화자극은 인출 방해자극, 배열 방해자극, 비관련 방해자극의 세 가지로 구성하였다. 인출 방해자극은 목표 단어의 음소인출에 방해를 주는 점화자극으로, 첫 번째 음절은 목 표단어와 동일한 반면, 두 번째 음절은 목표단어와 다른 음소들로 구성되어 있다. 예를 들어 목표단어가 ‘나비’일 경우 인출 방해자극 은 /나드/이다. 이는 ‘나비’의 /ㅂ/, / / / 의 인출에 혼란을 줄 수 있을 것이다. 배열 방해자극은 음소를 순차적으로 배열하는 데에 방해 를 주는 점화자극으로, 목표단어와 동일한 음소들로 이루어져 있 으나 첫 번째 음절과 두 번째 음절의 위치가 바뀌어 배열되었다. 목 표단어가 '나비'일 경우 배열 방해자극은 /비나/이다. 이는 음소들 을 / ㄴ///////ㅂ//// / 와 같은 순서로 배열시키는 데에 혼란을 줄 수 있을 것이다. 비관련 방해자극은 목표단어와 음운적으로 최대한 관련성이 없도록 하기 위해, 목표단어를 구성하는 자음 및 모음과 전혀 겹치지 않는 음소들을 배열하여 만들었다. 예를 들어 ‘나비’에 대한 비관련 방해자극은/캐토/이다.

모든 점화자극은 목표단어와 음절구조를 일치시킨 2음절 비단 어였다. 단어가 아닌 비단어로 제작한 이유는 의미 활성화로 인한 목표단어의 촉진가능성을 배제하기 위함이었다. 따라서 방해자극 이 비단어가 아닌, 아동에게 의미 있는 단어가 되는 경우를 제외하 여(예: ‘오이'의 배열 방해자극 /이오/), 2 차 단어목록에서 최종 목표 단어 목록과 방해자극 목록을 완성하였다. 18 개의 목표단어에 대 해 세 가지 점화자극이 동일한 수로 구성되었기 때문에, 점화자극 은 총 54 개이다. 이와 같은 목표단어와 점화자극 목록을 Appendix 1 에 제시하였다.

\section{음운부호화 점화 과제 제작}

목표단어는 모니터에 그림(시각자극)으로 제시되었고, 비단어로 제작된 점화자극은 헤드폰을 통해 소리(청각자극)로 제공되었다. 목표단어의 그림은 전문 일러스트레이터가 제작하였다. 제작된 그 림의 타당도 검증을 위해, 언어치료학 석사과정 15 명과 본 실험에 참여하지 않는 4,5 세 일반아동 3 명을 대상으로 목표그림을 보고 떠오르는 단어를 말하도록 하여 명명일치도를 측정하였다. 각 그림 당 최대 2 회의 명명기회가 주어졌으며, 첫 번째 시도에서 정확하게 명명할 경우 1점, 첫 번째 시도에서는 말하지 못하였으나 두 번째 시 도에서 정확하게 명명할 경우 0.5 점을 부여하였다. 전체 그림수에 대한 점수를 백분율로 구한 결과, 총 18 개의 문항 모두 평균 $95 \%$ 이 상의 타당도를 보였다.

점화자극은 3 개의 자극제시시간 조건(-300 ms, $0 \mathrm{~ms},+300 \mathrm{~ms})$, 즉 목표단어보다 $300 \mathrm{~ms}$ 전에, 목표단어와 동시에, 목표단어보다 $300 \mathrm{~ms}$ 나중에 제시되었다. 세 가지 점화자극과 세 개의 자극제시 시간 조건이 존재하기 때문에, 동일한 자극제시시간에서 하나의 목 표단어가 다른 점화자극에 대해 반복적으로 산출되지 않도록 하기 위해 목표단어를 3 개의 세트(A set, B set, C set)로 나누고 적절하게 섞어 Task A, Task B, Task C를 다음과 같이 구성하였다. Task A는 자극제시시간 -300 ms에서 A set (인출), B set (배열), C set (비관 련), 자극제시시간 $0 \mathrm{~ms}$ 에서 B set (인출), C set (배열), A set (비관 련), 자극제시시간 $+300 \mathrm{~ms}$ 에서 C set (인출), A set (배열), B set (비 관련)로 구성되어 있다. Task B 는 자극제시시간 - $300 \mathrm{~ms}$ 에서 C set (인출), A set (배열), B set (비관련), 자극제시시간 $0 \mathrm{~ms}$ 에서 A set 
(인출), B set (배열), C set (비관련), 자극제시시간 $+300 \mathrm{~ms}$ 에서 $\mathrm{B}$ set (인출), C set (배열), A set (비관련)로 구성되어 있다. Task C는 자극제시시간 -300 ms에서 B set (인출), C set (배열), A set (비관 련), 자극제시시간 $0 \mathrm{~ms}$ 에서 C set (인출), A set (배열), B set (비관 련), 자극제시시간 $+300 \mathrm{~ms}$ 에서 A set (인출), B set (배열), C set (비 관련)로 구성되어 있다. 이러한 방식으로 구성된 각 task를 대상자 의 $1 / 3$ 씩에게 실시하였다. 동일한 자극제시시간 내에서 목표단어는 점화자극의 유형에 상관없이 무작위 순서로 제시되었다. 이러한 실 험과제의 구성을 Appendix 2에 제시하였다.

실험 과제는 노트북에서 구현될 수 있도록 $\mathrm{DmDx}$ 소프트웨어를 사용하여 전산화 프로그램으로 제작되었다(Foster \& Foster, 2003). 자극제시시간 -300 ms에서의 구체적인 실험 과제는 Figure 1과 같
다. 우선 아동의 주의집중을 위해 $500 \mathrm{~ms}$ 동안 +표시가 화면에 제 시된다. 이후 자극제시시간 $-300 \mathrm{~ms}$ 에서 점화자극이 청각적으로 제시되고, $300 \mathrm{~ms}$ 의 자극 내 간격(inter stimulus interval, ISI) 제시 후 목표단어의 그림이 화면에 나타나면 아동은 바로 그 그림의 이 름을 말해야한다.

자극제시시간 $0 \mathrm{~ms}$ 에서의 실험 과제는, Figure 2에서 볼 수 있듯 이, 청각적 점화자극과 목표단어의 그림이 동시에 제시되면 아동은 해당 그림의 이름을 말해야한다.

자극제시시간 $+300 \mathrm{~ms}$ 실험 과제에서는 목표단어의 그림이 화 면에 나오고 나서 $300 \mathrm{~ms}$ 의 ISI 후 점화자극이 청각적으로 제시되 면, 그 이후 아동으로 하여금 목표단어의 이름을 말하도록 한다 (Figure 3).

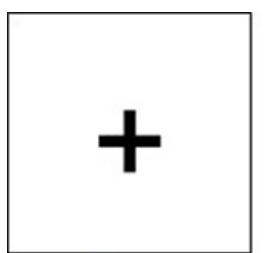

Fixation

$500 \mathrm{~ms}$
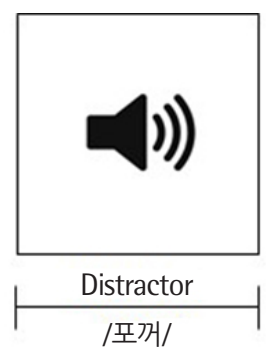

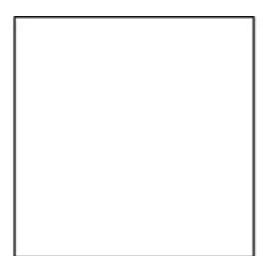

$|S|$

$300 \mathrm{~ms}$

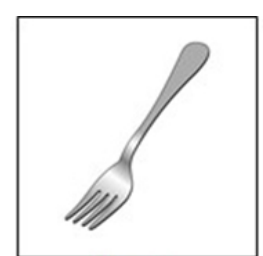

Target

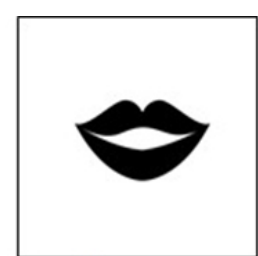

Response

Figure 1. Example of the retrieval distractor task in SOA '-300 ms'.

SOA = stimulus onset asynchrony; ISI = inter stimulus interval.

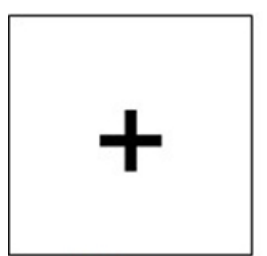

Fixation

$500 \mathrm{~ms}$
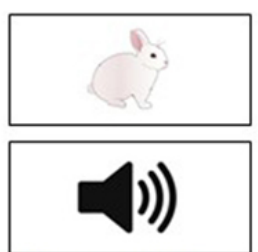

Distractor/Target

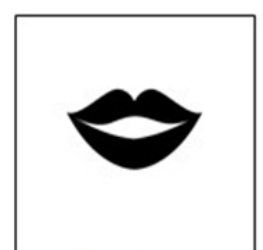

Response

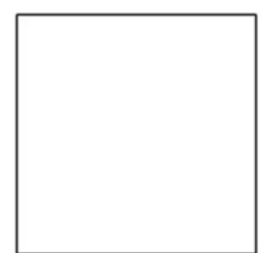

F

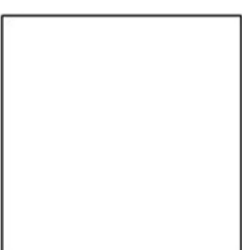

Figure 2. Example of the sequencing distractor task in SOA '0 ms'. SOA = stimulus onset asynchrony.

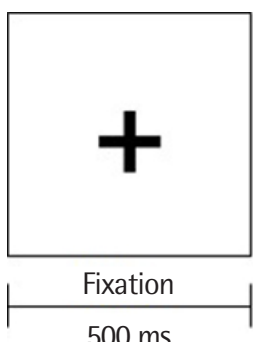

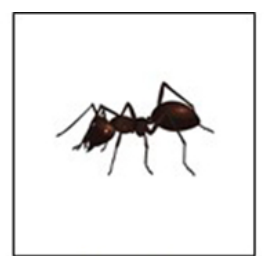

Target

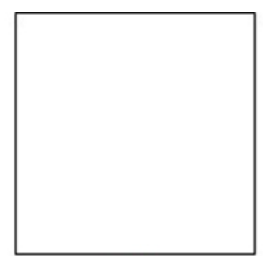

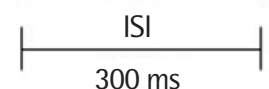
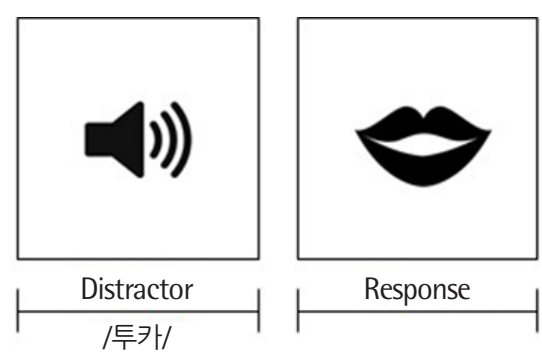

Figure 3. Example of the unrelated distractor task in SOA '+300 ms'. SOA = stimulus onset asynchrony; $I S \mid=$ inter stimulus interval. 


\section{실험 절차}

소음이 없는 조용한 방에서 검사자와 대상자가 마주보고 앉아 개별적으로 실험을 진행하였다. 대상아동에게 그림이 제시되는 모 니터를 응시하고, 헤드폰에서 나오는 소리를 집중해서 듣도록 하였 다. 연습문항을 통해 각 점화자극 유형과 각 자극제시시간 조건에 대한 검사방법을 충분히 숙지시킨 후 본 실험을 시작하였다. 실험 을 시작하기 전 목표단어가 아동의 어휘목록에 이미 존재하는 것 인지 확인하였고, 해당 그림을 보고 목표단어를 바로 말하지 못할 경우 아동으로 하여금 목표단어의 이름을 충분히 숙지하도록 하였 다. 각 자극제시시간 조건에서 그림을 보고 그림 이름을 명명하게 하였는데, 이때 그림 전, 중, 후에 제시되는 소리자극은 무시할 것을 강조하였다. 예를 들어 자극제시시간 $-300 \mathrm{~ms}$ 의 경우, 검사자는 아 동에게 "소리가 나오고 그림이 나와요. 소리와 상관없이 그림이 무 엇인지 말해주세요”와 같이 설명하였다.

\section{자료 처리}

4초 내에 주저하지 않고 목표단어의 이름을 정확하게 말한 경우 만 정반응으로 처리하였다. 틀린 반응뿐 아니라 목표단어의 이름 을 인출하기는 하였으나 4 초가 경과한 경우, 비유창성을 동반한 경 우 등도 모두 오반응으로 처리하였다. 이는 시간제한을 두지 않거 나 비유창성으로 인한 시간지연을 허용할 경우 반응시간 측정에 제한이 있을 것으로 판단하였기 때문이다. 또한 자극제시시간 $+300 \mathrm{~ms}$ 에서 청각적 점화자극이 나오기 전 그림 이름을 말하는 아 동이 간혹 있었는데, 이 경우 실험이 제대로 이루어지지 않은 것으 로 판단하여 분석에서 제외하였다. 정확도는 정반응수를 목표단어 의 총 개수로 나누어 백분율(\%)로 구하였다.

반응시간은 Check Vocal 프로그램을 사용하여, 청각적 점화자 극이 끝나는 시점부터 아동의 발화 시작 시점까지로 측정하였다.
오류가 많은 경우 제한된 정반응수로 인해 정확한 반응시간 측정 이 어려울 뿐 아니라, 갈등요인이 동반된 과제에서는 반응시간이 빠 르면 오류가 증가하는 반응시간-오류율의 교환효과가 나타날 수 있다(Bruyer \& Brysbaert, 2011). 이를 통제하기 위해 본 연구에서 는 측정된 반응시간을 정확한 반응의 수로 나누어 백분율(\%)로 산 출한 역효율지수(inverse efficiency score, IES)를 반응시간의 지표 로 사용하였다.

오류유형에 따른 오류율 분석을 위해 우선 대상자들이 실험 과 정에서 보인 오류를 유형별로 분류하였다. 그 결과 오류유형을 무 응답, 비유창성 동반, 음운 비활성화, 음운 부분활성화, 의미 활성 화로 분류할 수 있었다. 무응답은 4 초 내에 아무런 반응을 못한 경 우, 비유창성 동반은 간투사, 반복, 수정 등의 비유창성을 동반한 후 목표단어를 말한 경우(예: “어, 음, 그거, 나비”), 음운 비활성화 는 목표단어의 음소와 일치하는 음소를 전혀 포함하지 않은 비단 어를 산출한 경우(예: ‘나비'에 대해/도쿠/라고 말한 경우), 음운 부 분활성화는 목표단어의 음소 중 일부를 포함하는 비단어를 산출 한 경우(예: '개미'에 대해/개브/라고 말한 경우), 의미 활성화는 목 표단어와 의미적으로 관련이 있는 단어로 대체하여 반응한 경우 (예: '베개'에 대해/침대/라고 말한 경우)이다. 점화자극을 똑같이 따라한 오류는 관찰되지 않았다. 오류율은 각 오류유형별 개수를 전체 단어수로 나눈 후 백분율(\%)로 산출하였다.

통계 분석은 SPSS (Statistics Package for the Social Science) version 25 for Windows를 이용하였다. 집단 간 점화자극 유형 및 자 극제시시간 조건에 따른 정확도와 반응시간 분석에 대해, 그리고 집단 간 점화자극 유형 및 오류유형에 따른 오류율 분석에 대해 1 피험자 간-2피험자 내 혼합설계에 따른 반복측정 분산분석을 실시 하였다. 사후검정에 대해서는 집단 간 차이는 Scheffé 사후검정을, 집단 내 주효과는 Bonferroni 검정을, 상호작용효과는 COMPARE

Table 2. Accuracy (\%) of task performance according to distractors and SOAs in three groups

\begin{tabular}{|c|c|c|c|c|}
\hline SOA & Distractor & Pure SSD group $(\mathrm{N}=18)$ & $S S D+L D$ group $(N=8)$ & TD group ( $\mathrm{N}=18$ ) \\
\hline \multirow[t]{3}{*}{$-300 \mathrm{~ms}$} & $\mathrm{RD}$ & 88.89 (12.78) & $79.17(17.25)$ & $93.52(10.13)$ \\
\hline & SD & $80.55(18.30)$ & $68.75(18.77)$ & $86.11(15.40)$ \\
\hline & URD & $81.48(15.00)$ & $79.17(21.36)$ & $89.82(14.16)$ \\
\hline \multirow[t]{3}{*}{$0 \mathrm{~ms}$} & $\mathrm{RD}$ & 80.56 (14.29) & $81.25(16.52)$ & $87.96(9.58)$ \\
\hline & SD & $75.00(18.30)$ & 85.41 (13.91) & $92.59(10.26)$ \\
\hline & URD & $75.00(25.08)$ & $68.75(20.77)$ & $83.33(19.80)$ \\
\hline \multirow[t]{3}{*}{$+300 \mathrm{~ms}$} & $\mathrm{RD}$ & $85.96(13.16)$ & $72.92(21.56)$ & 87.50 (14.08) \\
\hline & SD & 80.28 (15.49) & $67.08(13.27)$ & $85.93(12.85)$ \\
\hline & URD & $80.74(10.39)$ & $63.75(20.81)$ & $87.78(12.63)$ \\
\hline
\end{tabular}

Values are presented as mean (SD).

$S S D=$ speech sound disorder; $S S D+L D=$ speech sound disorder with language disorder; $T D=$ typically developing; $S O A=$ stimulus onset asynchrony; $R D=$ retrieval distractor; $\mathrm{SD}=$ sequencing distractor; $\mathrm{URD}=$ unrelated distractor. 
syntax를 입력하여 분석하였다. 모든 연구질문에 대해 통계적 유의 성은 유의수준.5에서 해석하였다.

\section{연구결과}

\section{집단 간 점화자극 유형 및 자극제시시간에 따른 음운부호화 점화 과제 정확도 비교}

점화자극 유형과 자극제시시간 조건에 따른 각 집단별 음운부호 화 과제 정확도의 기술통계는 Table 2 와 같다. 전반적으로 $\mathrm{TD}$ 아동 이 pure SSD와 SSD+LD 아동보다 평균 정확도가 높다는 것을 알 수 있다. 그러나 점화자극 유형별 수행 양상은 자극제시시간 조건 에 따라 다소 상이하였다. 이러한 차이에 대한 통계분석 결과 집단 간 차이 $(F=8.65)$ 와 집단 내 점화자극 유형의 주효과가 유의하였으 나 $(F=4.38)$, 자극제시시간에 따른 주효과는 유의하지 않았다 $(F=2.00)$. 그리고 점화자극 유형과 자극제시시간 간 상호작용효과 는 유의하였으나 $(F=2.63)$, 점화자극 유형과 집단 간 $(F=.58)$, 자극 제시시간과 집단 간 $(F=2.49)$ 및 자극제시시간, 점화자극 유형, 집 단 간 상호작용효과는 모두 유의하지 않았다 $(F=.579)$.

사후검정 결과, 집단 간 차이의 경우 $\mathrm{TD}$ 집단에 비해 pure $\mathrm{SSD}$ 집단과 $\mathrm{SSD}+\mathrm{LD}$ 집단의 정확도가 유의하게 낮았고, 점화자극 유형 에 따른 차이의 경우 비관련 방해자극보다 인출 방해자극에서 정 확도가 유의하게 높았다. 자극제시시간과 점화자극 유형 간 상호작 용효과에 대해서는 자극제시시간 $-300 \mathrm{~ms}$ 에서는 배열 방해자극보 다 인출 방해자극에서, 자극제시시간 $0 \mathrm{~ms}$ 에서는 비관련 방해자 극보다 배열 방해자극에서, 자극제시시간 $+300 \mathrm{~ms}$ 에서는 비관련 방해자극보다 인출 방해자극에서 각각 정확도가 유의하게 높아, 자극제시시간에 따라 방해자극의 효과가 모두 상이한 것을 알 수

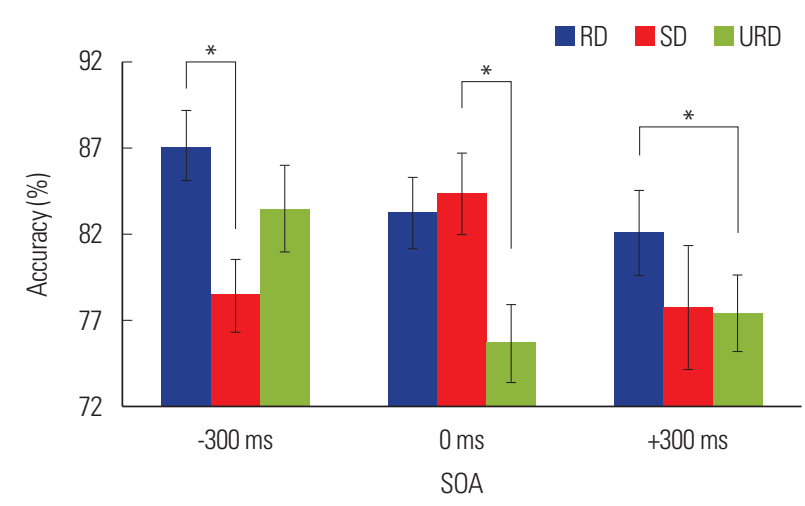

Figure 4. Accuracy of task performance according to distractors and SOA. SOA = stimulus onset asynchrony; $\mathrm{RD}=$ retrieval distractor, $\mathrm{SD}=$ sequencing distractor, URD = unrelated distractor. ${ }^{*} p<.05$.
있다(Figure 4).

\section{집단 간 점화자극 유형 및 자극제시시간에 따른 음운부호화 점화 과제 반응시간 비교}

점화자극 유형과 자극제시시간 조건에 따른 각 집단별 음운보호 화 과제 반응시간의 기술통계는 Table 3 과 같다. 전반적으로 TD 아 동이 pure SSD와 SSD+LD 아동보다 평균 반응시간이 빨랐고, 비 관련 방해자극보다 인출과 배열 방해자극에서 반응시간이 빨라졌 으나 집단과 자극제시시간에 따라 약간의 차이는 있었다. 이러한 차이에 대한 통계분석 결과 세 집단 간 반응시간의 차이가 유의하 였다 $(F=8.849)$. 집단 내 변수에 대해서는 점화자극 유형에 따른 차 이는 유의하였으나 $(F=14.257)$, 자극제시시간에 따른 차이는 유의 하지 않았다 $(F=2.471)$. 그리고 점화자극 유형과 집단 간 $(F=2.706)$, 점화자극 유형과 자극제시시간 간 $(F=5.468)$ 상호작용효과는 유의 하였던 반면, 자극제시시간과 집단 간 $(F=1.170)$, 점화자극 유형, 자 극제시시간 및 집단 간 $(F=1.488)$ 상호작용효과는 모두 유의하지 않았다.

주효과에 대한 사후검정 결과, $\mathrm{TD}$ 집단에 비해 $\mathrm{SSD}+\mathrm{LD}$ 집단의 반응시간이 유의하게 길었고, 비관련 방해자극보다 인출 방해자극 과 배열 방해자극에서 반응시간이 유의하게 짧았다. 자극제시시간 과 점화자극 유형 간 상호작용효과의 사후검정 결과, 자극제시시간 $0 \mathrm{~ms}$ 에서는 비관련 방해자극보다 인출과 배열 방해자극에서 반응 시간이 유의하게 짧았던 반면, 자극제시시간 $+300 \mathrm{~ms}$ 에서는 비관 련 방해자극과 배열 방해자극보다 인출 방해자극에서 반응시간이 유의미하게 짧아졌다. 집단과 점화자극 유형 간 상호작용효과의 사 후검정 결과, TD 집단은 배열 방해자극에서는 pure SSD와 SSD+LD

Table 3. Reaction time (ms) of task performance according to distractors and SOAs in three groups

\begin{tabular}{lcclr}
\hline SOA & Distractor & $\begin{array}{c}\text { Pure SSD group } \\
(\mathrm{N}=18)\end{array}$ & $\begin{array}{c}\text { SSD+LD group } \\
(\mathrm{N}=8)\end{array}$ & $\begin{array}{c}\text { TD group } \\
(\mathrm{N}=18)\end{array}$ \\
\hline \multirow{2}{*}{$300 \mathrm{~ms}$} & $\mathrm{RD}$ & $993.39(393.36)$ & $1,116.98(516.55)$ & $788.94(516.55)$ \\
& SD & $963.24(227.64)$ & $1,207.07(607.44)$ & $800.89(306.62)$ \\
& URD & $970.78(274.96)$ & $1,271.79(885.24)$ & $805.77(203.41)$ \\
$0 \mathrm{~ms}$ & RD & $974.62(270.23)$ & $1,002.02(722.39)$ & $760.53(330.71)$ \\
& SD & $1,141.33(432.03)$ & $1,071.17(445.20)$ & $705.89(220.70)$ \\
& URD & $1,333.60(620.02)$ & $1,793.98(1,182.13)$ & $1,098.50(761.27)$ \\
$+300 \mathrm{~ms}$ & RD & $893.82(369.25)$ & $1,096.81(489.67)$ & $869.49(299.24)$ \\
& SD & $1,025.15(450.59)$ & $1,543.19(710.18)$ & $848.13(350.15)$ \\
& URD & $1,234.65(712.97)$ & $1,929.39(1,052.52)$ & $795.38(281.81)$ \\
\hline
\end{tabular}

Values are presented as mean (SD).

$S S D=$ speech sound disorder; $S S D+L D=$ speech sound disorder with language disorder; TD= typically developing; $\mathrm{SOA}=$ stimulus onset asynchrony; $\mathrm{RD}=$ retrieval distractor; $\mathrm{SD}=$ sequencing distractor; $\mathrm{URD}=$ unrelated distractor. 


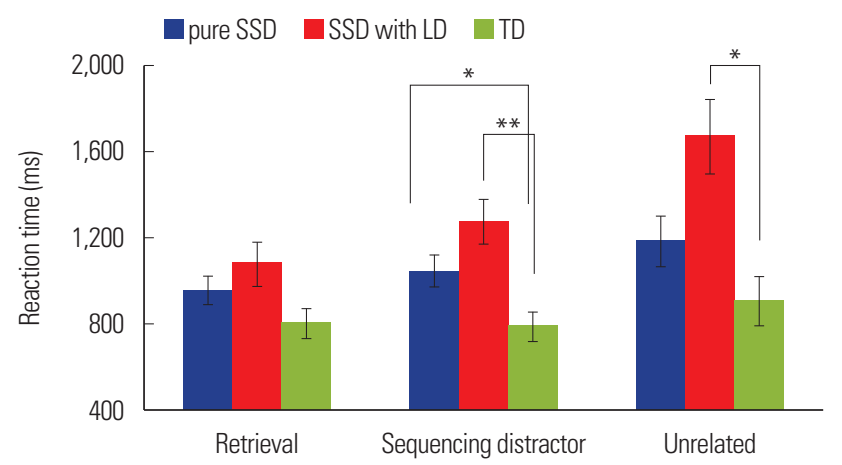

Figure 5. Reaction time of task performance according to distractors in three groups.

$S S D+L D=$ speech sound disorder with language disorder; $T D=$ typically developing.

${ }^{*} p<.05,{ }^{* *} p<.01$.

집단보다, 비관련 방해자극에서는 SSD+LD 집단에서보다 유의하 게 빠른 반응시간을 보여주었다(Figure 5).

\section{집단 간 점화자극 유형 및 오류유형에 따른 음운부호화 점화 과제 오류율 비교}

연구질문 1 의 결과에서 살펴보았듯이 자극제시시간에 따른 과 제수행의 정확도에 유의한 차이가 없었기 때문에, 오류율 비교에서 는 자극제시시간을 변수에서 제외하였다. 또한 총 54 개의 문항 중 52 개 이상 정반응하여 오류를 2회 이하 보인 일반아동 4 명은 해당 분석에서 제외하였기 때문에, 본 연구질문에 대한 일반아동의 대상 자 수는 14 명이었다. 점화자극 유형과 오류유형에 따른 각 집단별 음운보호화 과제의 오류율에 대한 기술통계는 Table 4 와 같다. TD 아동과 $\mathrm{SSD}+\mathrm{LD}$ 간 오류율 차이가 두드러졌고, 전반적으로 무반응 의 비율이 다른 오류유형보다 높았다. 무반응 이외의 오류유형은 점화자극 유형 및 집단에 따라 다소 상이한 양상을 보였다. 통계분 석 결과 집단간차이가 유의하였다 $(F=3.688)$. 집단 내 점화자극 유 형에 따른 오류율 $(F=1.574)$, 오류유형에 따른 오류율 $(F=13.422)$, 점화자극 유형과 오류유형의 상호작용효과 $(F=4.774)$ 가 유의하였 다. 그러나 점화자극 유형과 집단 간 $(F=.855)$, 오류유형과 집단 간 $(F=.414)$, 점화자극 유형, 오류유형, 집단 간 $(F=1.331)$ 상호작용효 과는 모두 유의하지 않았다.

주효과에 대한 사후검정 결과, $\mathrm{TD}$ 집단에 비해 $\mathrm{SSD}+\mathrm{LD}$ 집단의 오류율이 유의하게 높았고, 인출 및 배열 방해자극보다 비관련 방 해자극에서 오류율이 유의하게 높게 나타났다. 오류유형에 대해서 는 무응답과 음운 부분활성화 비율이 비유창성, 음운 비활성화, 의 미 활성화보다 유의하게 높았다. 점화자극 유형과 오류유형 간 상 호작용효과에 대한 사후검정 결과, 음운 비활성화는 인출과 배열
Table 4. Error ratio (\%) of task performance according to distractors and error types in three groups

\begin{tabular}{lcccc}
\hline SOA & Distractor & $\begin{array}{c}\text { Pure SSD group } \\
(\mathrm{N}=18)\end{array}$ & $\begin{array}{c}\text { SSD+LD group } \\
(\mathrm{N}=8)\end{array}$ & $\begin{array}{c}\text { TD group } \\
(\mathrm{N}=18)\end{array}$ \\
\hline RD & NR & $5.56(7.38)$ & $10.25(9.32)$ & $5.41(4.39)$ \\
& WD & $2.51(3.46)$ & $1.39(2.57)$ & $2.08(3.63)$ \\
& PD & $1.85(4.67)$ & $0.74(2.08)$ & $0.00(0.00)$ \\
& PPA & $3.40(4.72)$ & $9.59(6.46)$ & $4.81(5.28)$ \\
SD & SA & $1.27(2.45)$ & $1.39(2.57)$ & $0.84(2.15)$ \\
& NR & $6.17(7.60)$ & $10.58(6.95)$ & $4.41(5.48)$ \\
& WD & $4.40(9.48)$ & $0.69(1.96)$ & $2.38(3.59)$ \\
& PD & $1.87(2.72)$ & $0.74(2.08)$ & $0.42(1.57)$ \\
& PPA & $8.48(7.10)$ & $9.23(7.35)$ & $3.62(4.70)$ \\
& SA & $0.96(2.22)$ & $4.33(4.12)$ & $2.08(3.80)$ \\
& NR & $8.02(11.31)$ & $9.90(9.19)$ & $7.19(8.27)$ \\
& WD & $3.45(8.21)$ & $0.69(1.96)$ & $2.85(4.97)$ \\
& PD & $5.63(5.83)$ & $10.64(14.90)$ & $1.59(4.03)$ \\
& PPA & $3.12(4.00)$ & $3.69(4.53)$ & $2.40(4.75)$ \\
& SA & $0.93(2.13)$ & $4.29(3.99)$ & $1.98(2.76)$ \\
\hline
\end{tabular}

Values are presented as mean (SD).

$S S D=$ speech sound disorder; $S S D+L D=$ speech sound disorder with language disorder; $\mathrm{TD}=$ typically developing; $\mathrm{RD}=$ retrieval distractor; $\mathrm{SD}=$ sequencing distractor; $\mathrm{URD}=$ unrelated distractor; $\mathrm{NR}=$ no response, $\mathrm{WD}=$ with disfluency, $\mathrm{PD}=$ phonological deactivation, $\mathrm{PPA}=$ partial phonological activation, $\mathrm{SA}=$ semantic activation.

방해자극보다 비관련 방해자극에서 유의하게 높았던 반면, 음운 부분활성화는 비관련 방해자극보다 인출과 배열 방해자극에서 유 의하게 높았다.

\section{논의 및 결론}

본 연구에서는 말소리장애를 초래하는 기저요인 중 하나인 음운 부호화의 결함을 살펴보기 위해, 음운부호화 점화 과제를 제작하 여 pure SSD, SSD+LD, TD 아동의 수행력을 비교함으로써 음운부 호화 처리능력에 세 집단 간 어떠한 차이가 있는지를 알아보았다. 연구질문인 정확도, 반응시간, 오류율에 대한 결과들을 각각 살펴 보는 것보다, 세 결과를 종합적으로 파악하여 결론을 도출하는 것 이 말소리장애 아동의 특성을 파악하는 데에 도움이 될 것이다. 따 라서 세 연구질문에 대한 일련의 결과들을 종합적으로 정리하고 이에 대한 논의를 하고자 한다.

우선 집단 간 차이를 살펴보면, 방해자극 유형, 자극제시시간, 오 류유형에 상관없이, 정확도에서는 pure SSD와 SSD+LD 집단이, 반 응시간과 오류율에서는 $\mathrm{SSD}+\mathrm{LD}$ 집단이 $\mathrm{TD}$ 집단과 유의한 차이 를 보였다. SSD+LD 집단의 경우 모든 수행력에서 $\mathrm{TD}$ 집단과 차이 를 보임을 알 수 있다. 목표단어가 대상자들에게 친숙하고 발음하 
기 쉬운 단어들이었더라도, 어휘처리에 어려움이 있는 SSD+LD 아 동의 경우 방해자극이 있는 그림 이름대기 과제는 부담이 되는 과 제이다. 따라서 이들이 $\mathrm{TD}$ 집단보다 낮은 정확도와 긴 반응시간, 그리고 높은 오류율을 보였다는 결과는 대상집단의 특성상 당연 한 것으로 보인다. 반면 pure SSD 집단은 어휘능력을 포함한 전반 적인 언어능력에 $\mathrm{TD}$ 집단과 차이가 없는 아동들이었다. 그러나 목 표단어가 이들에게 매우 쉬운 단어들이었음에도 불구하고, 방해 자극의 동반은 SSD 아동들의 이름대기 정확도를 유의하게 떨어뜨 렸으며, 이는 방해자극이 이들에게 무시할 수 없는 간섭요인으로 작용하였음을 시사한다. Pure SSD는 다른 영역에는 아무런 문제 가 없고 단지 말소리에만 결함을 나타내는 장애라는 점을 상기할 때, 본 연구의 방해자극은 pure SSD 아동들의 취약점인 음운처리 활동에 부담감을 가중시켰고, 그로 인해 이와 같은 결과가 초래된 것으로 보인다.

대상자들의 수행력을 인출과 배열이라는 음운부호화와 관련하 여 해석하기 위해 방해자극 유형의 주효과 분석결과를 먼저 살펴 보면, 집단과 자극제시시간에 상관없이 정확도에서는 인출 방해자 극이, 반응시간과 오류율에서는 인출과 배열 방해자극이 비관련 방해자극보다 대상자들의 수행력을 유의하게 향상시켰다. 즉, 인출 방해자극과 배열 방해자극은 목표활동의 촉진에 기여하였고, 특히 인출 방해자극은 정확도 향상을 이끌어낼 정도로 그 효과가 컸다. 이러한 결과가 초래된 원인을 찾아내기 위해서는 본 연구의 방해자 극을 좀 더 자세히 살펴봐야 한다. 인출 방해자극은 첫 번째 음절 은 목표단어와 동일하지만 두 번째 음절은 목표단어와 다른 음소 들로 구성되어 있다. 목표단어와 일부 다른 음소들로 이루어졌기 때문에 목표음소들의 인출에 혼란을 준다는 의미에서 인출 방해 자극이라 명명하였다. 배열 방해자극은 목표단어와 동일한 음소들 로 구성되었으나 그 순서를 거꾸로 배치하였고, 음소들의 올바른 배열에 혼란을 준다는 의미에서 배열 방해자극이라 명명하였다. 이 처럼 인출과 배열 방해자극은 모두 화자의 음운처리활동을 간섭하 기 위해 제작되었지만, 그럼에도 불구하고 목표단어와 공유하는 음운정보 또한 존재하기 때문에 결과적으로 이것이 대상자들의 목 표반응을 촉진한 것으로 보인다. 이 중 인출 방해자극이 더욱 유의 한 촉진효과를 초래한 결과는 동일한 위치의 동일한 음절정보는 대상자들의 음운부호화에 매우 강력한 단서를 제공할 수 있음을 시사한다. 이것은 목표단어와 첫 음소가 일치하는 점화자극은 음 운산출완충기에서 첫 음소의 활성화를 향상시켜 궁극적으로 전체 단어의 산출속도를 빨라지게 한다는 선행연구들과 같은 맥락에서 해석할 수 있다(Dell, 1986; Jescheniak \& Schriefers, 2001; Meyer \& Schriefers, 1991; Schriefers, Meyer, \& Levelt, 1990).
선행연구에 의하면 시각적으로 그림이 제시된 후 약 $+300 \mathrm{~ms}$ 시 점에서 화자의 머릿속에서 음운부호화가 시작된다(Strijkers \& Costa, 2011). 그러나 Figure 4 를 살펴보면 인출 방해자극의 경우 자 극제시시간 $+300 \mathrm{~ms}$ 보다 이전 시점인 자극제시시간 $0 \mathrm{~ms}$ 와 자극 제시시간 $-300 \mathrm{~ms}$ 에서도 촉진효과가 있었고, 심지어 시간적으로 가장 차이가 나는 자극제시시간 $-300 \mathrm{~ms}$ 에서 그 효과가 두드러졌 다. 이것은 목표단어와 두운이 동일한 자극을 제시하였을 때 자극 제시시간 시점과 상관없이 음운부호화 과정이 촉진되었다는 선행 연구(Brooks \& MacWhinney, 2000)와 일치하는 결과이다. 입력된 자극은 일정 시간이 지나면 사라지기 마련이며, 불필요한 자극은 더 빨리 사라진다. 더불어 처리해야 할 과제들을 동시에 직면하는 것은 대상자의 주의할당에 큰 부담이 되는 일이다. 때문에 그림자 극과 동시에 단서가 제공되거나 화자의 자발적인 어휘처리 과정 중 단서가 제공되는 것보다는, 화자의 단기기억이 허용하는 내에서 순 차적으로 의미 있는 정보를 제공하는 것이 더욱 효과적이다. 예를 들어 /개느/라는 자극이 들어온 직후 '개미' 그림이 제시되면 불필 요한 /느/는 빨리 사라지고, 필요한 정보인 / 개/는 /개미/를 음운부 호화 하는 데에 도움이 된다. 단, 시각적 분석부터 조음활동까지 화 자의 인지처리활동이 시작되거나 그 중간에 정보가 들어오는 경우 는 그 이전 시점보다는 효과가 덜하다. 이러한 가설에 근거할 때 인 출 방해자극이 모든 자극제시시간에서 촉진효과가 있고, 더 나아 가 자극제시시간 $-300 \mathrm{~ms}$ 에서 가장 효과가 크다는 결과는 타당한 것으로 보인다.

반면 배열 방해자극은 자극제시시간과 관련하여 인출 방해자극 과는 다른 양상을 나타내었다. Figure 4에서 알 수 있듯이 배열 방 해자극은 자극제시시간 $0 \mathrm{~ms}$ 에서만 촉진효과가 있었으며, 이러한 현상은 반응시간에 대한 결과에서도 동일하였다. 배열 방해자극은 그 순서는 뒤바뀌어 있지만 모든 음소가 목표단어와 동일한 자극 으로, 연구자들이 배열 방해자극을 제작한 이유는 목표단어의 배 열순서에 혼란을 주기 위함이었다. 그러나 결과적으로 목표단어의 마지막 음절이 처음에 위치함으로써, 기억기제의 초두효과-(primacy effect)를 고려할 때, 위치의 혼란보다는 오히려 마지막 음절의 음 운정보를 잔존하게 하는 데에 더 큰 효과가 있었을 가능성을 배제 할 수 없다. 시각자극 후 $+300 \mathrm{~ms}$ 에서 음운부호화가 시작된다고 전 제할 때(Strijkers \& Costa, 2011), 첫 음소부터 마지막 음소까지의 인출은 $+300 \mathrm{~ms}$ 이후 순차적으로 이루질 것이다. 따라서 배열 방해 자극으로부터 얻을 수 있는 마지막 음절에 대한 정보는 그림자극 후 $+300 \mathrm{~ms}$ 이후 특정 시점과 상대적으로 멀리 떨어진 자극제시시 간 -300 ms에서는 유효하지 않았으나 좀 더 가까운 자극제시시간 0 에서는 효과가 있었던 것으로 보인다. 그러나 음소인출 이후 배열 
처리 과정을 진행하여야 하는 $+300 \mathrm{~ms}$ 이후의 특정 시점과 더욱 가까워진 자극제시시간 $+300 \mathrm{~ms}$ 에서는 연구자들의 의도대로 배열 된 방해자극이 화자의 음소배열 활동에 혼란을 주었을수 있다. 때문 에 자극제시시간 $+300 \mathrm{~ms}$ 에서는 배열 방해자극이 비관련 방해자극 만큼 대상자의수행력에부정적인 영향을준 것으로 보인다(Figure4).

반응시간의 경우 방해자극 유형과 집단 간 상호작용효과가 관찰 되었다. Figure 5 를 살펴보면, 인출 방해자극은 모든 집단에서 반응 시간을 단축시키는 데에 기여하여 집단 간 차이가 유의하지 않았 다. 그러나 배열 방해자극은 pure SSD와 SSD+LD 집단보다 TD 집 단의 반응시간을 유의하게 단축시켰다. 이러한 결과는 SSD 집단의 경우, 언어장애 동반 여부에 상관없이, 음소정보가 동일한 위치에 서 주어질 때 반응이 더욱 촉진됨을 시사하며, 따라서 이들에게 첫 음절 정보는 매우 강력한 단서가 된다는 것을 다시 한 번 확인할 수 있다. 더불어 비관련 방해자극에서 SSD+LD 집단의 반응속도가 두드러지게 느려졌다는 결과(Figure 5)로, 어떠한 음소정보도 공유 하지 않는 자극이 목표자극과 거의 동시에 입력될 때 이들이 받는 혼란의 정도는 다른 집단보다 훨씬 크다는 것을 알 수 있다. 이와 같 은 연구결과는 SSD 아동의 치료자극 선정 시 유의할 점에 대해 시 사하는 바가 있다. 즉, 첫 음절을 공유하는 단어들을 목표단어로 선 정한다면 각 단어들은 서로 음운정보에 대한 단서를 제공할 수 있 을 것이다. 이후 음운적으로 비슷한 소리가 들어있는 단어 중 배열 이 바뀐 단어들을 목표단어들로 제시한다면, 좀 더 도전적인 과제 가 될 것이다. 그러나 관련성이 없는 단어들을 목표단어들로 한꺼 번에 제시할 경우 혼란을 줄 가능성이 있으므로 치료자극 선정 시 주의하여야 할 것이다.

이상과 같은 결과로 인해 본 연구의 방해자극들에 연구자가 의 도하지 않았던 촉진효과가 발생하였음을 알 수 있다. 인출 방해자 극은 목표단어와 동일하지 않은 음소정보를 포함하기 때문에 그로 인해 화자의 음소인출 처리 과정에 억제효과가 있을 것으로 예상하 였으나, 이와 달리 자극어에 포함된 동일한 위치의 동일한 음소정 보는 가장 강력한 촉진효과로 작용하였다. 또한 배열 방해자극은 목표단어와 동일하지 않은 배열정보를 제공하기 때문에 그로 인해 화자의 음소배열 처리 과정에 억제효과가 있을 것으로 예상하였으 나, 이를 $+300 \mathrm{~ms}$ 직전에 제시한 경우 오히려 자극어에 포함된 음소 정보로 인해 촉진효과가 있음을 알 수 있었다. 이러한 결과는 오류 유형별 오류율 분석 결과에서도 확인할 수 있었다. 즉, 비관련 방해 자극에서는 음운 비활성화 오류가 유의하게 많았던 반면, 인출 방 해자극과 배열 방해자극에서는 음운 부분활성화 오류가 유의하게 많았다. 이러한 결과는 인출 방해자극과 배열 방해자극이 억제보 다 촉진의 기능을 하였음을 의미하며, 그 촉진이 목표단어와 공유
하는 음운정보로 인한 것임을 추측하게 해 준다.

방해자극들이 연구자들의 의도대로 기능을 하지는 않았지만, 그랬기 때문에 오히려 더욱 의미 있는 정보를 얻을 수 있었다. 우선 동일한 위치에서 첫 음절을 공유하는 점화자극은 목표자극 제시 전, 중, 후의 어떤 시점에서도 촉진효과를 초래하였다. 반면 마지막 음절의 음소정보를 공유하는 점화자극은 그림자극과 동시에 제공 될 때에만 촉진효과가 있었다. 이는 순차적인 음운정보의 처리 과 정에서 마지막 음절은 첫 음절보다 이후에 처리될 가능성, 이로 인 해 음운부호화 단계와 시간적으로 좀 더 가까운 자극제시시간 0 $\mathrm{ms}$ 에서만 효과가 있었을 가능성, 또는 위치 정보를 공유하지 않음 으로써 첫 음절 단서에서보다 입력정보가 빨리 사라질 가능성, 이 로 인해 마찬가지로 음운부호화 단계와 시간적으로 좀 더 가까운 자극제시시간 $0 \mathrm{~ms}$ 에서만 효과가 있었을 가능성 등을 생각해 볼 수 있다. 그러나 그보다 배열 방해자극이 자극제시시간 $+300 \mathrm{~ms}$ 에 서는 촉진이 아닌 억제효과의 기능을 하였다는 점에 주목할 필요 가 있다. 배열 과정은 목표음소들의 인출이 어느 정도 이루어진 후 인출된 음소들을 목표위치에 맞게 순서화하는 작업인 만큼, 언어 처리 과정상 시간적으로 후기단계에서 일어나는 일임을 추측할 수 있다. 이와 같은 이유로 자극제시시간 $+300 \mathrm{~ms}$ 에서는 배열 방해자 극이 말 그대로 방해자극으로 작용한 것으로 보인다. 무엇보다 자 극제시시간 $+300 \mathrm{~ms}$ 에서 배열 방해자극은 pure SSD와 SSD+LD 집단 모두에 부정적인 영향을 주었으나, $\mathrm{SSD}+\mathrm{LD}$ 집단에서 그 영 향이 더욱 컸다는 점을 간과하지 말아야 할 것이다. 이는 pure SSD 와 $\mathrm{SSD}+\mathrm{LD}$ 집단 둘 다 음운배열능력에 취약함이 있을 가능성, 그 러나 SSD+LD 집단에서 그 취약함이 더욱 두드러질 가능성을 시 사한다.

본 연구결과 $\mathrm{SSD}$ 집단, 특히 $\mathrm{SSD}+\mathrm{LD}$ 집단은 $\mathrm{TD}$ 집단보다 목표 단어 이외의 점화자극에 더욱 민감하게 방해를 받는 것을 알 수 있 었다. 그러나 방해 유형에 따라 오히려 촉진효과를 기대할 수도 있 으며 방해자극의 제시 시점에 따라서도 그 효과가 달라질 수도 있 다. 이와 같은 결과들을 도출한 본 연구는 무엇보다도 언어처리 과 정의 역동적이고 미세한 시간의 흐름상에서 음운부호화의 동적 처 리 과정을 살펴보았다는 점에서 의의가 있을 것이다.

\section{REFERENCES}

Bae, Y. S. (2018). Lexical retrieval performance ability depending on the types of auditory distractors in children with and without speech sound disorders (Master's thesis). Daegu University, Gyeongsan, Korea.

Bradford, A., \& Dodd, B. (1994). The motor planning abilities of phonologi- 
cally disordered children. European Journal of Disorders of Communication, 29(4), 349-369.

Bradford, A., \& Dodd, B. (1996). Do all speech-disordered children have motor deficits? Clinical Linguistics \& Phonetics, 10(2), 77-101.

Bradford-Heit, A., \& Dodd, B. (1998). Learning new words using imitation and additional cues: differences between children with disordered speech. Child Language Teaching and Therapy, 14(2), 159-179.

Brooks, P. J., \& MacWhinney, B. (2000). Phonological priming in children's picture naming. Journal of Child Language, 27(2), 335-366.

Bruyer, R., \& Brysbaert, M. (2011). Combining speed and accuracy in cognitive psychology: is the inverse efficiency score (IES) a better dependent variable than the mean reaction time (RT) and the percentage of errors (PE)? Psychologica Belgica, 51(1), 5-13.

Chiat, S. (1983). Why Mikey's right and my key's wrong: the significance of stress and word boundaries in a child's output system. Cognition, 14(3), 275-300.

Choi, E. H. (2000). A study of vocabulary development of Korean children (Master's thesis). Yonsei University, Seoul, Korea.

Dell, G. S. (1986). A spreading activation theory of retrieval in language production. Psychological Review, 93(3), 226-234.

Dell, G. S., Chang, F., \& Griffin, Z. M. (1999). Connectionist models of language production: lexical access and grammatical encoding. Cognitive Science, 23(4), 517-542.

Dodd, B. (2005). Differential diagnosis and treatment of children with speech disorder II. London: Whurr.

Dodd, B., \& McComack, P. (1995). A model of the speech processing for differential and treatment of children with speech disorder. London: Whurr.

Forster, K. I., \& Forster, J. C. (2003). DMDX: a Windows display program with millisecond accuracy. Behavior Research Methods, Instruments, \& Computers, 35(1), 116-124.

Jescheniak, J. D., \& Schriefers, H. (2001). Priming effects from phonologically related distractors in picture-word interference. The Quarterly Journal of Experimental Psychology, 54A(2), 371-382.

Kim, N. Y., \& Ha, J. W. (2014). Phonological representations in children with articulation and phonological disorders. Communication Sciences \& Disorders, 19(2), 226-237.
Kim, Y. T., \& Shin, M. J. (2004). Urimal Test of Articulation and Phonology (U-TAP). Seoul: Hakjisa.

Kim, Y. T., Hong, G. H., Kim, K. H., Jang, H. S., \& Lee, J. Y. (2009). Receptive \& expressive vocabulary test (REVT). Seoul: Seoul Community Rehabilitation Center.

Kim, Y. T., Sung, T. J., \& Lee, Y. K. (2003). Preschool receptive-expressive language scale (PRES). Seoul: Seoul Community Rehabilitation Center.

Levelt, W. J. (1989). Speaking: from intention to articulation. Cambridge, MA: MIT press.

Lim, H. C. (2004). Korean Raven's Coloured Progressive Matrices (K-CPM). Seoul: Guidance Korea.

Meyer, A. S., \& Schriefers, H. (1991). Phonological facilitation in pictureword interference experiments: effects of stimulus onset asynchrony and types of interfering stimuli. Journal of Experimental Psychology: Learning, Memory, and Cognition, 17(6), 1146-1160.

Meyer, D. E., \& Schvaneveldt, R. W. (1971). Facilitation in recognizing pairs of words: evidence of a dependence between retrieval operations. Journal of Experimental Psychology, 90(2), 227-234.

Pae, S., \& Kwak, K. C. (2011). Korean MacArthur-Bates Communicative Development Inventories (KM-B CDI). Seoul: Mindpress.

Posner, M. I., \& Snyder, C. R. R. (1975). Attention and cognitive control. In R. L. Solso (Ed.), Information processing and cognition: the Loyola symposium (pp. 55-85). Hillsdale, NJ: Erlbaum.

Rubin, H., \& Liberman, I. Y. (1983). Exploring the oral and written language errors made by language disabled children. Annals of Dyslexia, 33(1), 111120 .

Schriefers, H., Meyer, A. S., \& Levelt, W. J. (1990). Exploring the time course of lexical access in language production: picture-word interference studies. Journal of Memory and Language, 29(1), 86-102.

Strijkers, K., \& Costa, A. (2011). Riding the lexical speedway: a critical review on the time course of lexical selection in speech production. Frontiers in Psychology, 2, 356.

Wilshire, C., Singh, S., \& Tattersall, C. (2016). Serial order in word form retrieval: new insights from the auditory picture-word interference task. Psychonomic Bulletin \& Review, 23(1), 299-305. 
Ji-Hye Hwang, et al. • Phonological Encoding of Children with Speech Sound Disorder

Appendix 1. 목표어휘 및 청각적 점화자극(인출, 배열, 비관련) 목록

\begin{tabular}{cccccc}
\hline & No. & Target & Retrieval distractor & Sequencing distractor & Unrelated distractor \\
\hline Example & 1 & 가방 & 가덛 & 방가 & 티틴 \\
A set & 2 & 냄비 & 냄드 & 비냄 & 둑토 \\
& 1 & 나비 & 나드 & 비나 & 캐토 \\
& 2 & 포도 & 포뚜 & 도포 & 니키 \\
& 3 & 토끼 & 토브 & 끼토 & 기나 \\
& 4 & 네모 & 네누 & 모네 & 두키 \\
& 5 & 변기 & 변끄 & 기변 & 툭타 \\
& 6 & 땅콩 & 땅꾿 & 콩땅 & 빈둔 \\
B set & 1 & 비누 & 비모 & 누비 & 토캐 \\
& 2 & 개미 & 개느 & 미개 & 투카 \\
& 3 & 구두 & 구보 & 두구 & 터커 \\
& 4 & 고기 & 고브 & 기고 & 티타 \\
& 5 & 팬티 & 팬뜨 & 티팬 & 눔보 \\
& 6 & 당근 & 당깸 & 근당 & 캔탁 \\
& 1 & 포크 & 포끼 & 크포 & 니도 \\
& 2 & 나무 & 나보 & 무나 & 캐커 \\
& 3 & 베개 & 베꾸 & 개베 & 투투 \\
& 4 & 그네 & 그머 & 네그 & 도쿠 \\
& 5 & 공부 & 공도 & 부공 & 틴태 \\
& 6 & 김밥[김빱] & 김떰 & 빱김 & 딱팅 \\
\hline
\end{tabular}


Appendix 2. 실험 통제를 위한 제시자극 선정

\begin{tabular}{|c|c|c|c|c|c|c|c|c|}
\hline & \multicolumn{2}{|l|}{$\begin{array}{l}\text { Task A } \\
\text { (54개) }\end{array}$} & \multicolumn{3}{|c|}{$\begin{array}{l}\text { Task B } \\
\text { (54개) }\end{array}$} & \multicolumn{3}{|c|}{$\begin{array}{l}\text { Task C } \\
\text { (54개) }\end{array}$} \\
\hline$\Gamma$ & 7 & 1 & $\Gamma$ & 1 & 7 & $\Gamma$ & 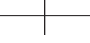 & 7 \\
\hline $\begin{array}{c}-300 \mathrm{~ms} \\
\text { (18개) }\end{array}$ & $\begin{array}{c}0 \mathrm{~ms} \\
\text { (18개) }\end{array}$ & $\begin{array}{c}+300 \mathrm{~ms} \\
\text { (18개) }\end{array}$ & $\begin{array}{c}-300 \mathrm{~ms} \\
\text { (18개) }\end{array}$ & $\begin{array}{l}0 \mathrm{~ms} \\
\text { (18개) }\end{array}$ & $\begin{array}{c}+300 \mathrm{~ms} \\
(18 \text { 개 })\end{array}$ & $\begin{array}{c}-300 \mathrm{~ms} \\
(18 \text { 개) }\end{array}$ & $\begin{array}{l}0 \mathrm{~ms} \\
\text { (18개) }\end{array}$ & $\begin{array}{c}+300 \mathrm{~ms} \\
(18 \text { 개 })\end{array}$ \\
\hline 1 & 1 & 1 & 1 & 1 & 1 & 1 & 1 & 1 \\
\hline $\begin{array}{l}\text { A set } \\
\text { 인출 }\end{array}$ & $\begin{array}{l}\text { B set } \\
\text { 인출 }\end{array}$ & $\begin{array}{l}\text { C set } \\
\text { 인출 }\end{array}$ & $\begin{array}{l}\text { C set } \\
\text { 인출 }\end{array}$ & $\begin{array}{l}\text { A set } \\
\text { 인출 }\end{array}$ & $\begin{array}{l}\text { B set } \\
\text { 인출 }\end{array}$ & $\begin{array}{l}\text { B set } \\
\text { 인출 }\end{array}$ & $\begin{array}{l}\text { C set } \\
\text { 인출 }\end{array}$ & $\begin{array}{l}\text { A set } \\
\text { 인출 }\end{array}$ \\
\hline 1 & 1 & 1 & 1 & 1 & 1 & 1 & 1 & $\perp$ \\
\hline $\begin{array}{l}\text { B set } \\
\text { 배열 }\end{array}$ & $\begin{array}{l}\text { C set } \\
\text { 배열 }\end{array}$ & $\begin{array}{l}\text { A set } \\
\text { 배열 }\end{array}$ & $\begin{array}{l}\text { A set } \\
\text { 배열 }\end{array}$ & $\begin{array}{l}\text { B set } \\
\text { 배열 }\end{array}$ & $\begin{array}{l}\text { C set } \\
\text { 배열 }\end{array}$ & $\begin{array}{l}\text { C set } \\
\text { 배열 }\end{array}$ & $\begin{array}{l}\text { A set } \\
\text { 배열 }\end{array}$ & $\begin{array}{l}\text { B set } \\
\text { 배열 }\end{array}$ \\
\hline \begin{tabular}{l|l} 
&
\end{tabular} & 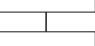 & 1 & 1 & 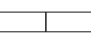 & 1 & 1 & 1 & 1 \\
\hline $\begin{array}{l}\text { C set } \\
\text { 비관련 }\end{array}$ & $\begin{array}{l}\text { A set } \\
\text { 비관련 }\end{array}$ & $\begin{array}{l}\text { B set } \\
\text { 비관련 }\end{array}$ & $\begin{array}{l}\text { B set } \\
\text { 비관련 }\end{array}$ & $\begin{array}{l}\text { C set } \\
\text { 비관련 }\end{array}$ & $\begin{array}{l}\text { A set } \\
\text { 비관련 }\end{array}$ & $\begin{array}{l}\text { A set } \\
\text { 비관련 }\end{array}$ & $\begin{array}{l}\text { B set } \\
\text { 비관련 }\end{array}$ & $\begin{array}{l}\text { C set } \\
\text { 비관련 }\end{array}$ \\
\hline
\end{tabular}




\section{국문초록}

\section{인출 방해자극과 배열 방해자극이 말소리장애 아동과 일반아동의 음운부호화 점화 과제 수행에 미치는 영향 황지혜' · 하지완23.3 \\ '대구대학교 일반대학원 재활과학과 언어치료전공, ${ }^{2}$ 대구대학교 언어치료학과, 일반대학원 재활과학과, ${ }^{3}$ 대구대학교 국제재활과학연구소}

배경 및 목적: 본 연구에서는 음운부호화를 인출과 배열이라는 세부적인 처리 과정으로 구분하여 살펴보기 위해 인출 방해자극과 배 열 방해자극으로 구성된 음운부호화 점화 과제를 제작하였고, 이를 이용하여 말소리장애 아동과 일반아동의 음운부호화 수행력을 비 교하였다. 방법: 연구대상은 4,5 세 순수 말소리장애 아동(pure SSD) 18 명, 언어발달지체를 동반한 말소리장애 아동(SSD+LD) 8 명, 일 반아동(TD) 18 명이었다. 인출, 배열, 비관련 방해자극을 청각적으로 제시하면서 목표단어의 이름을 명명하는 그림 이름대기 과제를 실 시하였다. 방해자극은 목표그림 제시 전 $-300 \mathrm{~ms}$, 목표그림과 동시, 목표그림 제시 후 $+300 \mathrm{~ms}$ 와 같이 자극제시시간(SOA)을 다양하게 하여 제공되었다. 결과: 정확도에서는 $\mathrm{SSD}$ 와 $\mathrm{SSD}+\mathrm{LD}$ 집단이, 반응시간과 오류율에서는 $\mathrm{SSD}+\mathrm{LD}$ 집단이 $\mathrm{TD}$ 집단과 유의한 차이를 보였다. 정확도에서는 인출 방해자극이, 반응시간과 오류율에서는 인출과 배열 방해자극이 비관련 방해자극보다 대상자들의 수행력 을 유의하게 향상시켰다. 인출 방해자극은 자극제시시간 $+300 \mathrm{~ms}$ 보다 이전 시점인 자극제시시간 $0 \mathrm{~ms}$ 와 자극제시시간 $-300 \mathrm{~ms}$ 에서도 촉진효과가 있었던 반면, 배열 방해자극은 자극제시시간 $0 \mathrm{~ms}$ 에서만 유의한 효과가 있었다. 비관련 방해자극에서는 음운 비활성화 오 류가 유의하게 많았던 반면, 인출과 배열 방해자극에서는 음운 부분활성화 오류가 유의하게 많았다. 논의 및 결론: SSD 집단, 특히 $\mathrm{SSD}+\mathrm{LD}$ 집단은 TD 집단보다 목표단어 이외의 자극에 더욱 민감하게 방해를 받을 수 있다. 그러나 방해 유형에 따라 오히려 촉진효과 를 기대할 수도 있으며 방해자극의 제시 시점에 따라서도 그 효과가 달라질 수 있다.

핵심어: 말소리장애, 음운부호화, 점화 과제, 인출 방해자극, 배열 방해자극

\section{참고문헌}

김나연, 하지완(2014). 조음음운장애아동과 일반아동의 음운표상의 질과 음운표상 부호화 능력 비교. Communication Sciences \& Disorders, 19(2), 226-237.

김영태, 성태제, 이윤경(2003). 취학전 아동의 수용언어 및 표현언어 척도(PRES). 서울: 서울장애인종합복지관.

김영태, 신문자(2004). 우리말조음-음운평가(U-TAP). 서울: 학지사.

김영태, 홍경훈, 김경희, 장혜성, 이주연(2009). 수용·표현어휘력검사(REVT). 서울: 서울장애인종합복지관.

배소영, 곽금주(2011). 한국판 맥아더-베이츠 의사소통발달평가(KM-B CDI). 서울: 마인드프레스.

배예슬(2018). 말소리장애 아동과 일반 아동의 청각적 Distractor 유형에 따른 그림 어휘인출 과제 수행력. 대구대학교 대학원 석사학위논문.

임호찬(2004). 한국판 레이븐 지능검사(CPM 지침서). 서울: 한국가이던스.

최은희(2000). 한국 아동의 어휘 발달 연구: 13-30개월 아동을 대상으로. 연세대학교 대학원 석사학위논문.

\section{ORCID}

황지혜(https://orcid.org/0000-0001-9464-4680); 하지완(https://orcid.org/0000-0002-1191-791X) 